ISSN : 2686 - 0953 (Online)

\title{
Analisis Risiko Produksi Kopi Robusta Di Jorong Pincuran Tujuah, Nagari Batipuh Baruah, Kecamatan Batipuh, Kabupaten Tanah Datar \\ Risk Analysis Of Robusta Coffee Production in Jorong Pincuran Tujuah, Nagari Batipuh Baruah, Batipuh District, Tanah Datar District
}

\author{
Sahnas Hidayah, Nofialdi ${ }^{2}$, Ifdal $^{3}$
}

${ }^{1}$ Mahasiswa Program Studi Agribisnis Fakultas Pertanian Universitas Andalas, Padang ${ }^{2}$ Staff Pengajar Program Studi Agribisnis Fakultas Pertanian Universitas Andalas, Padang ${ }^{3}$ Staff Pengajar Program Studi Agribisnis Fakultas Pertanian Universitas Andalas, Padang E-mail Korespondensi: sahnashidayah@gmail.com

\begin{abstract}
Abstrak
Penelitian ini dilaksanakan di Jorong Pincuran Tujuah, Nagari Batipuh Baruah, Kecamatan Batipuh, Kabupaten Tanah Datar. Tujuan penelitian adalah 1) Menganalisis risiko produksi yang terjadi pada kopi Robusta di Jorong Pincuran Tujuh, 2) Mendeskripsikan manajemen risiko yang dilakukan oleh petani pada produksi kopi Robusta di Jorong Pincuran Tujuh. Penelitian ini menggunakan metode survei dengan analisis data deskriptif kualitatif untuk tujuan pertama dan analisis kualitatif untuk tujuan kedua. Hasil penelitian mengungkapkan bahwa terdapat sebanyak 11 sumber risiko produksi Kopi Robusta di Jorong Pincuran Tujuh. Berdasarkan analisis tingkat risiko produksi dengan menggunkan pemetaan risiko, risiko pada kuadran I adalah hama penggerek buah kopi, kurang dalam penyiangan, cuaca saat penjemuran dan semut. Strategi pengelolaan risiko yang dilakukan petani kopi Robusta di Jorong Pincuran tujuh adalah stategi preventif dengan melakukan penyemprotan prekor, penyiangan yang efektif dilakukan oleh beberapa petani, dan berburu.
\end{abstract}

Kata kunci: risiko produksi, sumber risiko, manajemen risik.

\begin{abstract}
This research was conducted in Jorong Pincuran Tujuah, Nagari Batipuh Baruah, Batipuh District, Tanah Datar District. The research objectives were 1) Analyzing the production risk that occurred in Robusta coffee in Jorong Pincuran Tujuh, 2) Describing the risk management carried out by farmers on Robusta coffee production in Jorong Pincuran Tujuh. This study uses a survey method with qualitative descriptive data analysis for the first purpose and qualitative analysis for the second objective. The results revealed that there were as many as 11 risk sources of Robusta Coffee production in Jorong Pincuran Tujuh. Based on an analysis of the level of production risk by using risk mapping, the risk in quadrant I is coffee fruit borer, less weeding, weather during drying and ants. The risk management strategies carried out by Robusta coffee farmers in Jorong Pincuran seven are preventive strategies by spraying precursors, effective weeding carried out by some farmers, and hunting.
\end{abstract}

Keywords: production risk, risk sources, risk management. 


\section{PENDAHULUAN}

Kopi merupakan sumber penghasilan bagi kurang dari 1,5 juta jiwa petani kopi di Indonesia. Selain sebagai sumber penghasilan petani kopi, kopi juga merupakan salah satu hasil komoditi perkebunan yang memiliki nilai ekonomis yang tinggi di antara tanaman perkebunan lainnya dan berperan penting sebagai sumber devisa negara. Upaya meningkatkan produktifitas dan mutu kopi terus dilakukan sehingga daya saing kopi di Indonesia dapat bersaing di pasar dunia. Pengolahan kopi berperan penting dalam menentukan kualitas dan cita rasa kopi.

Sumatra Barat merupakan salah satu Provinsi dengan produksi kopi Robusta perkebunan rakyat terbesar di Indonesia. Dari data dapat dikatakan bahwa sebagian besar perkebunan kopi dibudidayakan oleh petani skala kecil yang mengakibatkan banyaknya risiko dan kesulitan untuk menjaga volume produksi dan kualitas stabil

Kabupaten Tanah Datar merupakan salah satu sentra kopi rakyat di Sumatra Barat. Kabupaten Tanah Datar memliki 3 komoditi ekspor yang menjanjikan yaitu komoditi kopi robusta, komoditi kopi arabika dan komoditi kemiri komoditi tersebut memiliki potensi menjadi komoditi unggulan 3 tahun mendatang

Kecamatan Batipuh merupakan salah satu dari 14 kecamatan di Tanah Datar yang di masa mendatang akan menjadikan Kopi Robusta sebagai komoditi potensial dan sekarang kopi rakyat ini berada dalam tahap pengembangan. Pada tahun 2016, kopi robusta menjadi komoditi perkebunan yang paling dominan yang di usahakan di Kecamatan Batipuh yakni seluas 141,50 Ha. Jorong Pincuran Tujuh sebagai salah satu wilayah diKecamatan Batipuh yang mayoritas penduduknya menjalankan pertanian rakyat kopi Robusta (BPS Tanah Datar, 2017). Wilayah perkebunan kopi rakyat jenis Robusta di Jorong Pincuran tujuah memiliki iklim yang baik untuk mengembangkan komoditas ini. Selain itu, dari sisi produksi, hasil produksinya berkualitas baik dan memiliki harga jual yang relatif tinggi dibandingkan daerah lain

Selama menjalankan kegiatan usahanya, perkebunan rakyat di Jorong Pincuran Tujuh ini memiliki risiko yang sering dihadapi oleh petani indikasi dari terdapatnya risiko pada usaha dapat dilihat dari produktivitas kebun yang berfluktuasi. Dari prasurvei yang dilakukan, didapatkan risiko yang sering terjadi di Jorong Pincuran Tujuh adalah hama penggerek daun dan penyakit karat daun. Dari informasi yang didapatkan petani di Pincuran Tujuh tidak melakukan pemupukan.

Berdasarkan latar belakang dan rumusan masalah diatas, maka penelitia ini bertujuan untuk:

1. Menganalisis risiko produksi yang terjadi pada kopi Robusta di Jorong Pincuran Tujuh

2. Mendeskripsikan manajemen risiko yang dilakukan oleh petani pada produksi kopi Robusta di Jorong Pincuran Tujuh

\section{METODE PENELITIAN}

Penelitian ini dilakukan di Jorong Pincuran Tujuh, Kecamatan Batipuh Kabupaten Tanah Datar, Sumatra Barat. Pemilihan tempat penelitian ini ditentukan dengan mempertimbangkan bahwa kawasan ini merupakan lokasi potensial pengembangan kopi di Sumatra. Metode yang digunakan dalam penelitian ini adalah metode survei. Metode survei adalah penyelidikan yang diadakan untuk memperoleh fakta-fakta dari gejalagejala yang ada dan mencari keterangan-keterangan secara faktual, baik tentang institusi sosial, ekonomi atau politik dari suatu kelompok ataupun suatu daerah.

Teknik sampling yang digunakan dalam penelitian ini adalah Probability sampling. Sampel ditentukan dengan simple random sampling, total populasi petani kopi di Jorong Pincuran Tujuh adalah 97 responden. Jumlah sampel yang diambil adalah berjumlah 30 yang menggunakan teknik slovin.

Data-data yang terdapat pada penelitian ini adalah data primer dan sekunder. 
Topik data dalam penelitian ini adalah: Sumber risiko pada proses produksi, Peluang dan dampak sumber risiko produksi, mendeskripsikan manajemen risiko yang dilakukan oleh petani untuk menangani risiko produksi robusta di Jorong Pincuran Tujuh.

\section{A. Gambaran Umum Daerah Penelitian \\ 1. Kondisi Geografis}

\section{HASIL DAN PEMBAHASAN}

Kecamatan Batipuh merupakan salah satu dari 14 kecamatan yang berada di Tanah Datar Provinsi Sumatra Barat. Kecamatan Batipuh terdiri dari 8 Nagari dan 48 Jorong. Lokasi penelitian difokuskan pada jorong pincuran tujuh yang merupakan salah satu jorong yang berada di Nagari Batipuh Baruah, Kecamatan Batipuh, Kabupaten Tanah Datar, Provinsi Sumatra Barat.

Secara geografis Jorong Pincuran Tujuh terletak di dataran tinggi dengan luas wilayah sebesar 7,04 km2 dan sedangkan untuk Jorong Pincuran Tujuh sebanyak 482 orang. Topografi nagari ini tergolong dataran tinggi dengan ketinggian dari permukaan laut mencapai 676 meter. Dengan curah hujan rata-rata pertahun 1900- $2000 \mathrm{~mm}$ dengan lama hari hujan 221 hari.

\section{Potensi Agribisnis Jorong Pincuran Tujuh}

Penggunaan lahan didominasi oleh tanaman perkebunan mencapai $28,37 \%$ dan sawah mencapai $25,74 \%$. Potensi sumber daya alam yang dimiliki jorong Pincuran tujuh dari sektor pertanian dimanfatkan untuk perkebunan yaitu Kopi Robusta dan kulit manis, serta untuk pemukiman masyarakat.

Tanaman Perkebunan yang paling banyak diusahakan di Jorong Pincuran Tujuh adalah Kopi Robusta dengan luas tanam 141,50 Ha. Petani Kopi Robusta di Jorong Pincuran ini hanya melakukan pengolahan kopi sampai pada tahap penjemuran, setelah dilakukan penjemuran petani akan mengantarkan kopi mereka ke Heller yang berada didekat rumah mereka untuk digiling dan langsung di jualkan kepada Heller tersebut yang merupakan tengkulak di Jorong Pincuran Tujuh.

\section{A. Karakteritik Petani Responden}

1. Umur

Dari hasil wawancara didapatkan petani yang berumur 15-49 tahun sebanyak 11 orang, 50-64 tahun sebanyak 17 orang dan $>64$ tahun sebanyak 2 orang, dapat dilihat pada tabel 1 .

Tabel 1. Karakteristik Petani Responden Berdasarkan Umur Petani pada Usahatani Kopi Robusta di Jorong Pincuran Tujuh

\begin{tabular}{cccc}
\hline No & Umur & Jumlah (orang) & Persentase \\
\hline 1 & $15-49$ & 11 & $36,67 \%$ \\
\hline 2 & $50-64$ & 17 & $56,67 \%$ \\
\hline 3 & $<64$ & 2 & $6,66 \%$ \\
\hline & Total & 30 & $100 \%$ \\
\hline
\end{tabular}

2. Pendidikan

Dari hasil wawancara didapatkan tingkat pendidikan formal petani adalah SD sebanyak 17 orang (56,67\%), SMP 6 orang (20\%) SMA 5 orang (16,67\%) dan D3/S1 2 orang $(6,66 \%)$, dapat dilihat pada tabel 2.

Tabel 2. Karakteristik Petani Responden Berdasarkan Tingkat Pendidikan Petani pada Usahatani Kopi Robusta di Jorong Pincuran Tujuh

\begin{tabular}{cccc}
\hline No & Pendidikan & Jumlah (orang) & Persentase \\
\hline 1 & SD & 17 & $56,67 \%$ \\
\hline 2 & SMP & 6 & $20 \%$ \\
\hline 3 & SMA & 5 & $16,67 \%$ \\
\hline 4 & D3/S1 & 2 & $6,66 \%$ \\
\hline & Total & 30 & $100 \%$ \\
\hline
\end{tabular}


3. Luas Lahan

Dari hasil wawancara didapatkan Luas lahan milik petani di Jorong Pincuran Tujuah pada komoditi kopi Robusta adalah $\geq 0,5$ ha sebanyak 15 orang $(50 \%)$ dan $>0,5 \mathrm{Ha}$ 15 orang (50\%) Luas lahan milik petani berimbang, dapat dilihat pada tabel 3.

Tabel 3. Karakteristik Petani Responden Berdasarkan Luas Lahan Milik Petani pada Usahatani Kopi Robusta di Jorong Pincuran Tujuh

\begin{tabular}{cccc}
\hline No & Luas Lahan & Jumlah (orang) & Persentase \\
\hline 1 & $\leq 0,5$ & 15 & $50 \%$ \\
\hline 2 & $>0,5$ & 15 & $50 \%$ \\
\hline & Total & 30 & $100 \%$ \\
\hline
\end{tabular}

4. Lama Berusahatani Kopi

Dari hasil wawancara didapatkan dari pengalaman berusahatani, pengalaman usahatani $<10$ tahun sebanyak 6 orang atau 20\%, pengalaman berusahatani 10-20 tahun terdapat sebanyak 5 orang atau $16,67 \%$, dan pengalaman berusahatani $>20$ tahun sebanyak 19 orang atau 63,33\%, dapat dilihat pada tabel 8.

Tabel 4. Karakteristik Petani Responden Berdasarkan Lama Berusahatani Kopi Robusta di Jorong Pincuran Tujuh

\begin{tabular}{cccc}
\hline No & Lama Berusahatani (Tahun ) & Jumlah (orang) & Persentase \\
\hline 1 & $<10$ & 6 & $20 \%$ \\
\hline 2 & $10-20$ & 5 & $16,67 \%$ \\
\hline 3 & $>20$ & 19 & $63,33 \%$ \\
\hline & Jumlah & 30 & $100 \%$ \\
\hline
\end{tabular}

5. Umur kopi

Berdasarkan hasil wawancara didapatkan petani di Jorong Pincuran Tujuh memiliki tanaman berumur $>20$ tahun, dapat dilihat pada tabel 9

Tabel 5. Karakteristik Petani Besponden Berdasarkan Umur Kopi Robusta di Jorong Pincuran Tujuh

\begin{tabular}{cccc}
\hline No & Umur Kopi (tahun) & Jumlah (orang) & Persentase \\
\hline 1 & $\leq 20$ & 0 & - \\
\hline 2 & $>20$ & 30 & $100 \%$ \\
\hline & Total & 30 & $100 \%$ \\
\hline
\end{tabular}

6. Status Kepemilikan Lahan

Dari hasil wawancara didapatkan bahwa lahan yang dijadikan petani untuk membudidayakan kopi robusta adalah lahan milik sendiri yaitu $100 \%$ atau 30 petani responden, dapat dilihat pada tabel 6

Tabel 6. Karakteristik Petani Responden Berdasarkan Status Kepemilikan Lahan di Jorong Pincuran Tujuh

\begin{tabular}{cccc}
\hline No & Status Kepemilikan Lahan & Jumlah (orang) & Persentase \\
\hline 1 & Milik Sendiri & 30 & $100 \%$ \\
\hline 2 & Sewa & 0 & - \\
\hline & Total & 30 & $100 \%$ \\
\hline
\end{tabular}

Status kepemilikan laan milik sendiri akan mempengaruhi petani dalam melakukan usahanya. Petani yang mempunyai lahan sendiri maka akan mempunyai tanggung jawab yang lebih besar dibandingkan dengan yang tidak mengusahakan dilahan pribadi.

7. Status Pekerjaan Pokok

Dari hasil wawancara didapatkan bahwa 56,67\% atau 17 orang petani responden menjadikan usahatani kopi menjadi pekerjaan pokok mereka, untuk komoditi lain yang dijadikan pekerjaan pokok mereka adalah sebesar 33,3\% atau 10 petani responden, sedangkan dari luar usahatani sebesar 10,03\% atau 3 petani responden, dapat dilihat pada tabel 7 
Tabel 7. Karakteristik Petani Responden Berdasarkan Status Pekerjaan Pokok Petani Kopi di Jorong Pincuran Tujuh

\begin{tabular}{cccc}
\hline No & Status Pekerjaan Pokok & Jumlah (orang) & Persentase \\
\hline 1 & Petani Kopi & 17 & $56,67 \%$ \\
\hline 2 & Petani lainnya & 10 & $33,3 \%$ \\
\hline 3 & Diluar Usahatani & 3 & $10,03 \%$ \\
\hline & Total & 30 & $100 \%$
\end{tabular}

Dari tabel 10 dapat dilihat bahwa 56,67\% atau 17 orang petani responden menjadikan usahatani kopi menjadi pekerjaan pokok mereka, untuk komoditi lain yang dijadikan pekerjaan pokok mereka adalah sebesar 33,3\% atau 10 petani responden, sedangkan dari luar usahatani sebesar 10,03\% atau 3 petani responden.

\section{B. Risiko Kopi Robusta Di Jorong Pincuran Tujuh}

1. Budidaya Kopi Robusta Di Jorong Pincuran Tujuh

Budidaya yang dilakukan petani kopi Robusta di Jorong Pincuran Tujuh saat ini adalah :

a. Pemupukan

Berdasarkan hasil wawancara dengan petani responden, hanya terdapat 5 petani responden yang menggunakan pupuk, pupuk yang digunakan antara lain pupuk kandang, NPK, urea.

b. Pemangkasan

Dari hasil wawancara di lapangan petani resonden melakukan pemangkasan. Menurut petani pemangkasan ini dilakukan untuk memudahkan petani pada saat melakukan panen.

c. Pengendalian Organisme Penggang Tanaman OPT)

Berdasarkan hasil wawancara, untuk pengendalian hama dan penyakit hampir seluruh petani responden tidak ada yang melakukan pengendalian, petani lebih memilih untuk membiarkan hama dan penyakit menyerang.

d. Panen

Berdasarkan hasil pengamatan di lapangan usahatani kopi mengalami produksi pertama kali pada umur 5 tahun dan umur tanaman kopi Robusta di Jorong Pincuran Tujuh saat ini sudah lebih 20 tahun. Dari wawancara bersama responden panen dilakukan satu kali dalam satu tahun yaitu pada bulan Juni.

e. Pasca panen

Dari 30 petani responden tidak ada yang melakukan pembersihan buah dan juga sortasi buah kopi, menurut pendapat petani kegiatan itu tidak dibutuhkan karna kopi yang mereka hasilkan tetap akan terjual. Petani kopi di Jorong Pincuran Tujuh hanya melakukan penjemuran.

2. Identifikasi Sumber Risiko yang terjadi pada Produksi Kopi Robusta di Jorong Pincuran Tujuh

Identfikasi sumber risiko pada usahatani kopi Robusta merupakan langkah awal yang dilakukan sebelum melaksanakan manajemen risiko untuk mengatasi hal tersebut. Hal pertama yang dilakukan adalah mencari informasi untuk mengetahui penyebab risiko yang merugikan petani, yang dapat dilihat pada tabel 8 . 
Tabel 8. Sumber Risiko Produksi Kopi Robusta yang Terjadi di Jorong Pincuran Tujuh

\begin{tabular}{|l|l|c|c|}
\hline Kode & \multicolumn{1}{|c|}{ Risiko } & Petani & Persen (\%) \\
\hline A & Pemeliharaan & & \\
A1 & Hama Monyet & 20 & $66,67 \%$ \\
A2 & Hama Musang & 18 & $60 \%$ \\
A3 & Hama Kelalawar & 6 & $20 \%$ \\
A4 & Hama Babi & 5 & $16,67 \%$ \\
A5 & Hama Penggerek Buah & 22 & $73,33 \%$ \\
A6 & Hama Semut & 30 & $100 \%$ \\
A7 & Penyakit Karat Daun & 30 & $100 \%$ \\
A8 & Penyakit Bercak Daun & 30 & $100 \%$ \\
A9 & Kurang efektif dalam melakukan penyiangan & $30 \%$ & $100 \%$ \\
\hline B & Pascapanen & & \\
B1 & Cuaca & 30 & $100 \%$ \\
B2 & Petani yang tidak melakukan sortasi & 30 & $100 \%$ \\
\hline
\end{tabular}

Dari Tabel 8 menunjukan bahwa tidak semua risiko yang terjadi pada petani sampel. Pada usahatani Kopi robusta di Pincuran Tujuh terdapat sumber risiko produksi. Risiko Produksi pada usahatani terdapat pada pengolahan lahan, pembibitan, penanaman, pemupukan, pemeliharaan, dan panen yang disebbkan oleh faktor alam dan manusia

1. Pemeliharaan

a. Adanya hama

Risiko hama ini dialami oleh seluruh petni. Hama yang menyerang tanaman kopi adalah monyet, musang, kelalawar, babi dan hama penggerek buah. Adapun untuk hama monyet akan bergelantungan di pohon kopi dan menginjak pohon kopi sehingga buah kopi menjadi jatuh dan rusak. Kemudian musang akan memakan buah kopi yang sudah masak. Lalu ada kelalawar akan memakan buah kopi yang sudah masak. Selanjutnya ada babi babi yang menyerang lahan akan menginjak pohon kopi petani. Kemudian ada hama penggerek buah kopi hama ini menyerang ini membuat biji kopi menjadi kosong didalamnya. Dan selanjutnya ada semut risiko semut ini dialami oleh semua petani.

b. Adanya Penyakit

Risiko penyakit dirasakan oleh semua petani, penyakit yang menyerang tanaman kopi yaitu karat daun dan bercak daun akan tetapi menurut petani penyakit pada kopi robusta tidak terlalu berpengaruh.

c. Kurang efektif dalam melakukan penyiangan

Petani di Jorong Pincuran Tujuh masih belum memperhatikan tanaman kopi dengan kurangnya melakukan penyiangan pada lahan kopi miliknya. Pertumbuhan gulma dan benalu bagi petani kopi menjadi risiko yang menyebabkan tanaman kopi menjadi kurang nutrisi dan sulit dalam melakukan pemanenan.

2. Pascapanen

a. Cuaca

Cuaca yang tidak menentu di Jorong Pincuran Tujuh mengakibatan penjemuran menjadi tertunda. Risiko ini mengakibatkan mutu kopi menurun dikarenakan kopi mengalami proses kimia.

b. Petani yang tidak melakukan sortasi

Menurut Angara \& Marini (2011: 81) Setelah dipanen, buah harus disortir dan dibersihkan. Hal ini bertujuan untuk memisahkan buah berdasarkan kondisinya ( buah belum matang, terlalu matang dan buah rusak. risiko ini menyebabkan kualitas dan mutu kopi menjadi rendah. 
3. Evaluasi dan Penilaian Sumber Risiko Produksi Kopi Robusta Jorong Pincuran Tujuh

Evaluasi dan penilaian sumber risiko dilakukan menggunakan pemetaan risiko. Frekuensi dan dampak risiko produksi Kopi Robusta diperoleh dari pengamatan dan wawancara langsung kepada petani berdasarkan skala pengukuran yang ada. Nilai frekuensi dan dampak risiko produksi dapat dilihat pada Tabel 9.

Tabel 9. Hasil Skor Risiko Produksi Kopi Robusta di Jorong Pincuran Tujuh

\begin{tabular}{llllllll}
\hline Kode & \multicolumn{1}{c}{$\begin{array}{c}\text { Sumber Risiko } \\
\text { Produksi }\end{array}$} & $\begin{array}{c}\text { Probabi } \\
\text { litas }\end{array}$ & Kategori & Dampak & Kategori & Skor & $\begin{array}{c}\text { Kategor } \\
\text { i }\end{array}$ \\
\hline A & Pemeliharaan & & & & & & \\
\hline A1 & Hama Monyet & 2,067 & Rendah & 2,17 & Tinggi & 4,48 & Rendah \\
\hline A2 & Hama Musang & 2,4 & Rendah & 1,57 & Rendah & 3,77 & Rendah \\
\hline A3 & Hama Kelalawar & 0,7 & Rendah & 0,7 & Rendah & 0,49 & Rendah \\
\hline A4 & Hama Babi & 0,5 & Rendah & 0,5 & Rendah & 0,25 & Rendah \\
\hline A5 & Hama Penggerek Buah & 3,43 & Tinggi & 2,93 & Tinggi & 10,05 & Tinggi \\
\hline A6 & Hama Semut & 4,6 & Tinggi & 1,97 & Tinggi & 9,06 & Tinggi \\
\hline A7 & Penyakit Karat Daun & 2 & Rendah & 1 & Rendah & 2 & Rendah \\
\hline A8 & Penyakit Bercak daun & 2 & Rendah & 1 & Rendah & 2 & Rendah \\
\hline A9 & $\begin{array}{l}\text { Kurang efektif dalam } \\
\text { melakukan penyiangan }\end{array}$ & 3 & Tinggi & 2,2 & Tinggi & 6,6 & Tinggi \\
\hline C & Pascapanen & & & & & & \\
\hline C1 & Cuaca & $\mathbf{2}$ & Tinggi & 2 & Tinggi & 10 & Tinggi \\
\hline & Rata-rata & $\mathbf{2 , 5 7}$ & & $\mathbf{1 , 6}$ & & $\mathbf{4 , 8 7}$ & \\
\hline
\end{tabular}

Gambar 1 berikut menunjukan letak masing-masing sumber risiko produksi kopi Robusta di Jorong Pincuran Tujuh.

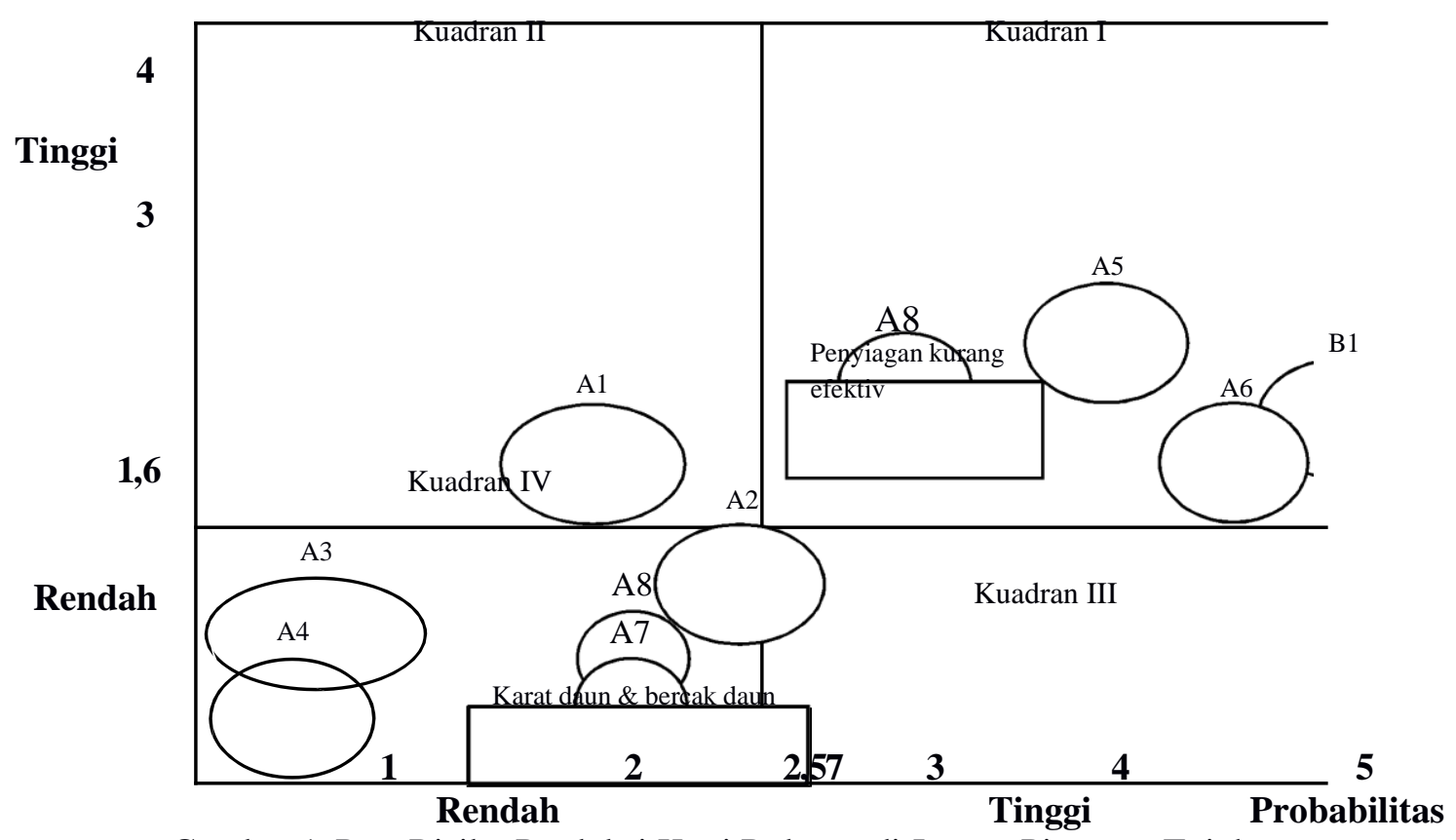

Gambar 1. Peta Risiko Produksi Kopi Robusta di Jorong Pincuran Tujuh 
Berdasarkan peta risiko terebut, dapat diketahui sumber risiko dari masing-masing risiko diantaranya:

1. Kuadran I

Kuadran I yaitu sumber risiko yang memiliki probabilitas kejadian yang tinggi dan dampak yang paling berpengaruh bagi petani di Jorong Pincuran Tujuh. Sumber risiko yang berada pada kuadran I adalah hama penggerek buah, semut, kurang efektif dalam melakukan penyiangan dan cuaca.

2. Kuadran II

Kuadran II merupakan kuadran yang memiliki sumber risiko yang tidak sering terjadi tetapi memiliki dampak yang tinggi terhadap produksi. Sumber risiko produksi yang berada pada kuadran II ini yaitu hama monyet.

3. Kuadran IV

Pada kuadran IV merupakan kuadran dengan sumber risiko yang jarang terjadi dan dampak terhadap usahatani kopi juga rendah. Sumber risiko yang terdapat pada kuadran IV yaitu hama musang, kelalawar, babi, penyakit karat daun dan penyakit bercak daun.

C. Pengelolan Risiko Produksi Kopi Robusta di Jorong Pincuran Tujuh

1. Penanganan Risiko yang Dilakukan oleh Petani Kopi Robusta di Jorong Pincuran Tujuh

a. Strategi Preventif

i. Semprot Rekor

Semprot rekor yang dilakukan petani di Jorong Pincuran Tujuh bertujuan untuk mengendalikan semut yang mengganggu petani dalam proses panen.

ii. Penyiangan

Penyiangan efektiv dapat mengurangi pertumbuhan gulma yang berada disekitar tanaman kopi. Petani di Jorong Pincuran Tujuh masih sangat sedikit melakukan penyiangan yang efektiv rata-rata petani di Jorong Pincuran Tujuh masih melakukan penyiangan dua kali dalam satu tahun, namun ada beberapa petani yang sudah mulai melakukan penyiangan satu kali satu bulan.

iii. Berburu

Apabila populasi monyet dan babi sudah mulai menggangu lahan milik petani maka mereka akan berburu untuk menekan populasi monyet dan babi yang menyerang.

Strategi preventif yang dilakukan petani di Jorong Pincuran untuk mengurangi frekuensi terjadi risiko digambarkan pada peta risiko, yang dapat dilihat pada gambar 7

Dampak

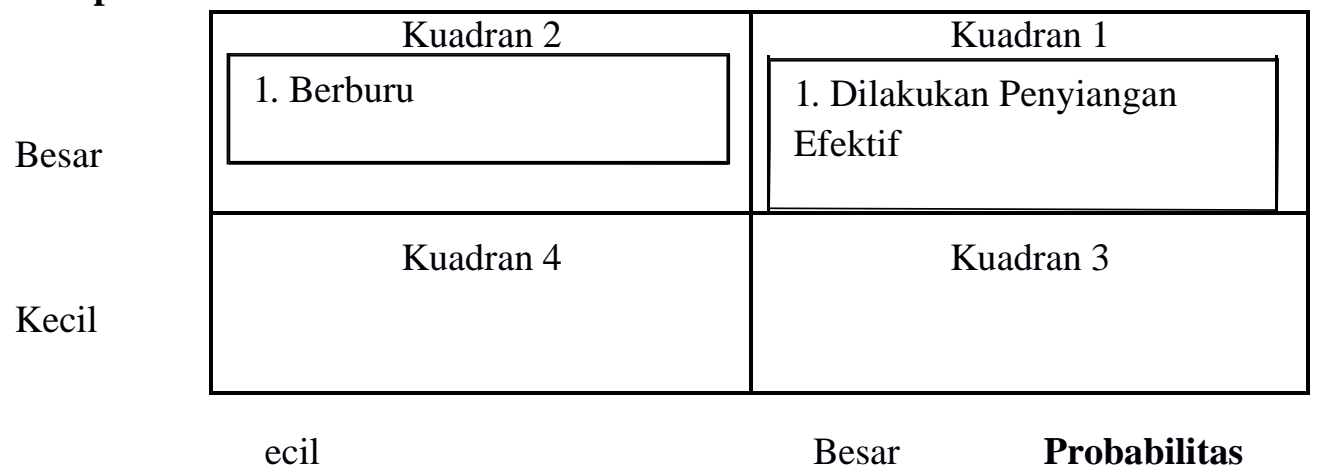

Gambar 2. Strategi Preventif yang Digunakan Petani Kopi di Jorong Pincuran Tujuh

b. Strategi Mitigasi

Strategi mitigasi risiko digunakan untuk meminimalkan dampak yang ditimbulkan oleh risiko. Namun dari beberapa penanganan risiko dengan strategi mitiasi tersebut petani kopi Robusta di Jorong Pincuran Tujuh belum ada yang melakukan strategi 
mitigasi tersebut untuk mengurangi dampak yang ditimbulkan sumber risiko pada kuadran 1 dan 2.

\section{Penanganan Risiko yang dapat dilakukan oleh petani kopi Robusta di Jorong Pincuran Tujuh}

a. Membuat atau memperbaiki sistem dan prosedur

i. Pengaturan jarak tanam

Cara menghindari risiko yang terjadi akibat jarak tanam ini dapat dilkukan pengaturan jarak tanam sesuai dengan GAP. Pemilihan jarak tanam akan memperkecil risiko terjadinya risiko, terutama dari terjangkitnya hama dan penyakit.

ii. Penggunaan pupuk

Dengan pemberian pupuk dan pemberian pupuk yang sesuai kebutuhan akan memperbaiki kondisi daya tahan tanaman terhadp lingkungan ekstrem dan dapat meningkatkan produksi dan mutu hasil yang tinggi.

iii. Mencabut tanaman yang terkena penyakit

iv. Pemetikan buah kopi sesuai standar

Saat panen tiba petani kopi di Jorong Pincuran Tujuh memetik buah kopi mereka tidak selektif. Kebiasaan pemetikan ini harus ditinggalkan dan memetik buah yang memang sudah sesuai standar panen (buah merah).

b. Memasang atau memperbaiki fasilitas fisik

i. Memasang perangkap untuk hama penggerek buah kopi

Hama ini dapat dikendalikan dengan memasang perangkap PBKo (Brocap Trap) alat ini menggunakan dan dilengkapi dengan senyawa Hypotan yang di produksi oleh Pusat Penelitian Kopi dan Kakao Indonesia (Puslitkoka).

ii. Peremajaaan tanaman kopi

Peremajaan tanaman kopi adalah upaya untuk menggantikan tanaman yang secara ekonomis sudah tidak menguntungkan lagi karna produktifitasnya rendah.

iii. Penggeringan dengan pengering mekanis

iv. Penjemuran dengan menggunakaan alat para-para, lantai jemur dan terpal

\section{A. Kesimpulan}

\section{PENUTUP}

Berdasarkan hasil penelitian yang telah dilakukan maka dapat diambil kesimpulan mengenai penelitian ini, yaitu:

1. Terdapat 11 sumber risiko produksi Kopi Robusta di Jorong Pincuran Tujuh risiko yang paling banyak dialami petani. Berdasarkan analisis tingkat risiko produksi dengan menggunkan pemetaan risiko, risiko pada kuadran I adalah hama penggerek buah kopi, kurang dalam penyiangan, cuaca saat penjemuran dan semut. Sumber risiko ini memiliki frekuensi dan dampak yang tinggi bagi petani Kopi robusta di Jorong Pincuran Tujuh.

2. Strategi pengelolaan risiko yang dilakukan petani kopi Robusta di Jorong Pincuran tujuh adalah stategi preventif dengan melakukan penyemprotan prekor, penyiangan yang efektif dilakukan oleh beberapa petani, dan berburu.

B. Saran

Berdasarkan kesimpulan penelitian apat ditemukan saran sebagai berikut:

1. Petani kopi Robusta di Jorong Pincuran tujuh perlu melakukan pemeliharaan terhadap tanaman kopi milik mereka seperti pemberian pupuk sesuai dengan kebutuhan tanaman, melakukan penyiangan yang efektif.

2. Umur kopi yang sudah tua sudah harus dilakukan peremajaan, karna umur kopi yang sudah tua menyebabkan tanaman sudah tidak produktif dalam menghasilkan.

3. Pentingnya melakukan penanganan sumber risiko yang memiliki frekuensi tinggi dan berdampak tinggi bagi petani. Apabila dibiarkan terus menurus maka produksi kopi Robusta akan terus menurun setiap tahunnya. 


\section{DAFTAR PUSTAKA}

Anggara dan Marini. Kopi Si Hitam Mengguntungkn Budidaya dan pemasaran. Yogyakarta: Cahaya Atma Pustaka. 117 hal

Badan Pusat Statistik. 2017. Statistik Kopi Indonesia 2016. Badan Pusat Statistik. Jakarta.

BPS Tanah Datar. 2017. Kecamatan Batipuh Dalam Angka. BPS Kabupaten Tanah Datar. Batipuh.

Departemen pertanian. 2016. Peatihan Budi Daya Berkelanjutan (Good Agriculture Practices-GAP) dan Pascapanen (Post-Harvest) Kopi Robusta

Direktorat Jenderal Perkebunan. 2013. Pedoman Teknis Pengembangan Tanaman Kopi Tahun 2014. Direktorat Jenderal Perkebunan. Jakarta.

Nasparida, Wiwit. 2019. Analisis Risiko Produksiu dan Risiko Harga Usahatani kopi arabika ( Coffea Arabika) Dikoperasi Solo Radjo Nagari Aiedingin Kecamatan Lembah gmanti Kabupaten Solok. [Skripsi]. Padang. Fakultas Pertanian Universitas Andalas

Rakasiwi, D. 2018. Faktor Produksi pada Usahatani Kopi di Desa Sukapura Kabupaten Sumberjaya Tahun 2016. [skripsi]. Bandar Lampung. Fakultas Keguruan dan Ilmu Pendidikan Universitas Lampung. 